\title{
https://dx.doi.org/10.4314/iijikm.v10i2.8 \\ Assessment of Information and Communication Technologies Usage by Maize Farmers in Afijio Local Government Area of Oyo State, Nigeria
}

\author{
Oke O.O., Adeoye A.S., Jatto K.A., Adelusi, F.T. and Ojo-Fakuade F.F. \\ Department of Agricultural Extension and Management \\ Federal Colle ge of Forestry, Ibadan, P.M.B 5087, Jericho Hill, Ibadan , Nigeria \\ "Corresponding email: saadeoye06@gmail.com;
}

\begin{abstract}
The study was carried out to assess the information and communication technology usage by maize farmers in Afijio Local Government Area of Oyo State. The study was necessitated by persistent poor communication of new technologies from research institutes which has hampered the productivity and livelihood of farmers. The parameters assessed include socio-economic characteristics of the respondents, ICT devices used, extent of radio usage, extent of mobile phone usage, effect of radio on maize farming, effect of mobile phone on maize farming, and constraints to effective use of ICT among respondents, respectively. A multistage sampling procedure was used for sample selection with $30 \%$ random selection of 10 wards which were Aawe, Imini, and Ilora with 8 villages selected randomly, and from each of these 8 selected villages, 10 respondents were selected systematically to give rise to a total of 80 respondents as sample size. A well-structured questionnaire was used for data collection while frequencies, percentages, chi-square and pearson product moment correlation were used for data analysis. The results showed that $60.0 \%$ of the respondents were male while $40.0 \%$ were female. The findings revealed that the use of radio, television and mobile phone has increased the income and livelihood of the maize farmers due to new methods learnt from agricultural programmes, also maize farmers have been exposed to latest technology on maize production through watching of documentaries and communicating with other maize farmers and customers. The study also showed the problems faced by the respondents were irregular power supply, high cost of ICT devices, and inadequate knowledge on technical know-how. It was therefore recommended that Maize farmers should be encouraged to access and utilize ICTs by supporting, them financially and materially by the governments and private sectors/donor agencies. Government should improve on electricity supply to the rural areas which will enable the farmers to utilize the ICT devices.
\end{abstract}

Keywords: Information Communication Technologies, Usage, Maize farmers

\section{Introduction}

Information and Communication

Technologies play important roles in every aspect of human activities today, including agriculture. The key player in agriculture are the farmers and their ability to use the technologies defines the role of ICT in agricultural generally (Nwagwu \& Opeyemi,
2015). In increasing access and exchanging of information, ICT offer the potential to increase efficiency productivity, competitiveness and growth in various aspects of agricultural sectors. Farmers that engage in commercial agriculture in large scale might be expected to be using cameras, computing devices, digital imaging, the 
Assessment of Information and Communication Technologies usage by maize farmers in Afijio local government area of Oyo state

internet and Wide Area Networking(WAN), Wi-Fi, SMS services, Wireless Access Protocol(WAP) based internet access. Those that engage in Agriculture in small scale utilize various other forms of Information and Communication Technology such as mobile phones, computer and the internet. Of all technologies, the mobile phone is certainly an instrument of choice for many farmers, both large and small scale (FAO, 2013). Mobile phones are cheap, easy to manage, power efficient and encourages personalised interactions. Mobile phones enable farmers to compare prices more efficiently and to link up with others buyers who were not previously easily accessible. Mobile phones help to improve the link between farmers and traders, creating opportunities for small scale producers in the area. ICT use in Agriculture moves in regular procession just like in many developing areas (FAO 2010). The major problems in adoption of ICT in rural setting are ICT illiteracy, availability of relevant and localised contents in own languages, easy and affordable accessibility and awareness and willingness to adopt new technologies. The potential benefits of ICT to farmers and farm processes call for need to understand factors that might influence the use of the technologies by farmers (Davis \& Addom, 2010). Over 80 percent of the farming population in Nigeria are small holders residing mostly in rural areas (Anamam, 2013). Small farms are mainly responsible for self sufficiency of food in Africa and cultivation of export crops. They are also very significant in world development with $50 \%$ of world's population depending on them. The usage of Information and Communication Technology maize farmers improve their knowledge of production and also enable the maize farmers to know and get aware of new innovation and also to know different varieties of maize. Maize is one of the commonly cultivated food crop in Nigeria, as it is eaten in various dishes and forms the basis for most of the meals prepared by the average Nigeria e.g (pap). Corn is a crop, cheaper than rice and wheat which is the most consumed cereals, and its affordability make maize hugely important food (Olaniyi \& Ismail, 2016). In the study of Temu and Msya (2014), the capacities of ICT on food security are related to improving communication between research system, farmers and extension, improving accessibility to information regarding inputs, introducing technologies, providing more 
Assessment of Information and Communication Technologies usage by maize farmers in Afijio local government area of Oyo state

rapid accessibility to high quality information, ensuring information about the appropriate time and places for optimised sales of Agricultural products decreasing Agricultural product losses.

Over the years, rural farmers depend on indigenous or local knowledge for improved farming system. Such knowledge refers to skill and experience gain through oral tradition and practice over many generations (Muriithi \& Ogaleh, 2009). Acquisition of such primitive skill by rural farmers has not helped to improve Agricultural yield. All that is witnessed in rural agricultural system range from poor farm yield, emergence of new crop and animal diseases resistant, weed and pests that attack farm crops, implement poor quality fertilizer. In Sub-Sahara Africa, the predominant carriers of information have traditionally been radio, television and newspapers. Recently, mobile phone technology have diffused very rapidly in the region, providing faster and multidirectional communication and information exchange opportunities for rural dwellers, farmers, extension workers and agricultural firms. Some of the key factors affecting the use of ICT in agriculture are inappropriate ICT policies especially those addressing agriculture, and the fact that not all the farmers have low-end ICT such as radio and television. Irregular power supply in Nigeria is a common feature that can act as a major barrier to the use of ICT (Olatokun, 2009). Also, some farmers who might be aware of the communication technologies may not use them to obtain information due to some barriers such as their level of education, level of their income, old age, all these may impede the farmers from using the information communication technologies. Some constraints in the use of ICT may includes; unavailability of the communication gadgets, unaffordability of the communication technologies (Gilwald, 2010.)

\section{Methodology}

This study was carried out in Afijio Local Government Area of Oyo State. A multistage sampling procedure was used to select respondents for the study. The first stage involved purposive selection of Afijio local Government Area for this study due to the availability of maize farmers in the Area. The $2^{\text {nd }}$ stage involved $30 \%$ random selection of 10 wards in Afijio Local Government Area, namely; Aawe, Imini and Ilora 1 . The $3^{\text {rd }}$ stage was simple random selection of 8 villages from the selected 
Assessment of Information and Communication Technologies usage by maize farmers in Afijio local government area of Oyo state

wards which are Aba Igara, Aba Pana, Aba Idi Eemi, Aba Ayetoro, Aba Pastor, Aba Onifa, Ilu Aje and Onikoko respectively while the $4^{\text {th }}$ stage was systematic random sampling of 10 respondents from each village selected. In all 80respondents were selected for the study. Data was collected from the respondents with a well-structured questionnaire. The data were analyzed with descriptive statistics such as frequency distribution, percentages while inferential statistics were chi-square and pearson product moment correlation to test the hypothesis of the study.

\section{Results and Discussion}

Socio-economic characteristics of the respondents

The results shows that $60.0 \%$ of the respondents were male while $40.0 \%$ were female .This indicated that both genders are involved in maize farming, but males are more involved than females. The results buttress the work of Temu (2010), that more men are engaged in maize farming than women. Also respondents above 50years has the highest percentage of $33.8 \%$,followed by $27.5 \%$ with the age less than 30years while 31-40years has the lowest percentage of $13.5 \%$ of the total population. This shows that the respondents in their middle age engaged more in maize farming than the younger farmers. The result of the marital status of the respondents shows that $62.5 \%$ of the respondents were married, $20 \%$ were single and $17.5 \%$ were widowed. This shows that most of the respondents are married, which implies that they are matured and responsible, this was in line with the findings of Akinbile (2007) who stated that marriage confers responsibility. According to the table, $31.3 \%$ do not have education at all, $17.5 \%$ have primary education, $12.6 \%$ have secondary education, $30.0 \%$ have OND/NCE and $8.8 \%$ have HND/BSC. This implies that most of the respondents were illiterates and very few have secondary education. This means there is problem of availability of relevant and localised contents in own languages and not able to adopt new technologies (Davis and Adom 2010).The result also shows that $26.2 \%$ practise Islamic religion while $68.8 \%$ are Christian and only $5.0 \%$ practise traditional religion. This means that whether you are Muslim or Christian does not affect your being involve in maize farming. The result further shows the secondary occupation of the respondents aside from maize farming, 43.8\% are into trading, $15.0 \%$ are artisan, 
Assessment of Information and Communication Technologies usage by maize farmers in Afijio local government area of Oyo state

and $18.7 \%$ are civil servants while $22.5 \%$ do not have any secondary occupation they are fully into maize farming. This indicates that majority of the respondents are engaged in trading as their secondary occupation in the study area. The result revealed that the level of employment of the respondents $60.0 \%$ are full time maize farmers and $40.0 \%$ are part

Table 1: Socio-economic characteristics of the respondents $(n=80)$ time farmers which implies that a higher percentage of the farmers population are into maize farming.

\begin{tabular}{|c|c|c|}
\hline Variable & Frequency & Percentage \\
\hline \multicolumn{3}{|l|}{ Sex } \\
\hline Male & 48 & 60.0 \\
\hline Female & 32 & 40.0 \\
\hline Total & 80 & \\
\hline \multicolumn{3}{|l|}{ Age } \\
\hline Less than 30years & 22 & 27.5 \\
\hline 31-40years & 11 & 13.5 \\
\hline 41-50years & 20 & 25.0 \\
\hline Total & 80 & 100.0 \\
\hline \multicolumn{3}{|l|}{ Marital status } \\
\hline Single & 16 & 20.0 \\
\hline Married & 50 & 62.5 \\
\hline Widowed & 14 & 17.5 \\
\hline Total & 80 & 100.0 \\
\hline \multicolumn{3}{|l|}{ Educational level } \\
\hline No formal education & 25 & 31.1 \\
\hline Primary education & 14 & 17.5 \\
\hline Secondary education & 10 & 12.6 \\
\hline OND/NCE & 24 & 30.0 \\
\hline
\end{tabular}


Assessment of Information and Communication Technologies usage by maize farmers in Afijio local government area of Oyo state

\begin{tabular}{lll}
\hline HND/BSC & 7 & 8.8 \\
Total & $\mathbf{8 0}$ & $\mathbf{1 0 0 . 0}$ \\
Religion & & \\
Islam & 21 & 26.2 \\
Christianity & 55 & 68.8 \\
Traditional & 4 & 5.0 \\
Total & $\mathbf{8 0 . 0}$ & $\mathbf{1 0 0 . 0}$ \\
Secondary occupation & & \\
Trading & 35 & 43.8 \\
Artisan & 12 & 15.0 \\
Civil servant & 15 & 18.7 \\
None & 18 & 22.5 \\
Total & $\mathbf{8 0}$ & $\mathbf{1 0 0 . 0}$ \\
Level of employment & & \\
Full time & 48 & 60.0 \\
Part time & 32 & 40.0 \\
Total & $\mathbf{8 0}$ & $\mathbf{1 0 0 . 0}$
\end{tabular}

The results in table 2 reveals that $96.3 \%$ of the respondents used radio as their ICT device, followed by mobile phone $86.3 \%$, television (65.0\%), internet (35.0\%), and computer (22.5).This result is in agreement with the findings of Arokoyo (2003) that radio, mobile phone and television remained the major ICTs used for extension service delivery especially in the rural areas. Similarly, Adejo and Haruna (2009) stated that these classes of ICT devices (radio ,television and mobile phone) are ideal for rural areas, cheap to set up, easy to use and meeting the important needs of the farmers.

Table 2: ICT Devices and facilities used by maize farmers $(n=80)$

\begin{tabular}{lll}
\hline Devices & Yes & No \\
\hline Radio & $77(96.3)$ & $3(3.8)$ \\
Television & $52(65.0)$ & $28(35.0)$ \\
Computer & $18(22.5)$ & $62(77.5)$
\end{tabular}


Assessment of Information and Communication Technologies usage by maize farmers in Afijio local government area of Oyo state

Internet 28(35.0) 52(65.0)

Mobile phone 69(86.3) 11(13.8)

Percentage in parentheses

Table 3 shows that $46.3 \%$ of the respondents occasionally used radio to listen to agricultural programme, while $37.5 \%$ always used radio to listen to agric programme, followed by $15.0 \%$ of respondents who rarely used radio and lastly $1.3 \%$ never listened to agriculture programme on radio. This implies that majority of the respondents occasionally used radio to listen to agricultural programmes. The result also shows that $26.3 \%$ of the respondents occasionally used radio as medium of advert while $33.8 \%$ never used radio as medium of advert. This implies that a higher number of maize farmers in the study area never used radio frequently.

Table 3: Extent of Usage of Radio by maize farmers $(n=80)$

\begin{tabular}{|c|c|c|c|c|}
\hline Radio & Always & Occasionally & Rarely & Never \\
\hline $\begin{array}{l}\text { I use radio to listen to agric } \\
\text { programmes }\end{array}$ & $30(37.5)$ & $37(46.3)$ & $12(15.0)$ & $1(1.3)$ \\
\hline I use radio as medium of advert & $16(20.0)$ & $21(26.3)$ & $16(20.0)$ & $27(33.8)$ \\
\hline
\end{tabular}

Percentage in parentheses

The results in table 4 shows that $62.5 \%$ of the respondents used mobile phone to source for information from extension agents, followed by $27.5 \%$ who occasionally used mobile phone and only $7.5 \%$ never used mobile. This indicates that majority of the maize farmers in the study area used mobile phone because it is easy to handle, fast, less expensive and easy to operate compared to other modern ICT facilities such as internet, social media etc. Arokoyo (2005) reported that mobile phone is one of the commonest classes of ICT facilities used for extension delivery services especially in the rural areas. The table further shows that $65.0 \%$ of the respondents always used mobile phone to transact business with the customers. This implies that with the use of mobile phone, maize farmers in the study area were transacting business with their customers on 
Assessment of Information and Communication Technologies usage by maize farmers in Afijio local government area of Oyo state

regular basis. Also $51.3 \%$ which is the while only $5.0 \%$ seldom use mobile phone average percentage of the respondents use to source for information on credit facilities. mobile phone to source for agro-inputs such as chemicals, fertilizers and seeds. Also $53.8 \%$ of the respondents use mobile phone This indicates that a higher number of respondents use mobile phone for business transaction on regular basis.

to source for information on credit facilities

Table 4: Extent of usage of Mobile phone by maize farmers $(n=80)$

\begin{tabular}{lllll}
\hline Mobile phone & Always & Occasionally & Rarely & Never \\
\hline I use mobile phone to get $50(62.5)$ & $22(27.5)$ & $2(2.5)$ & $6(7.5)$ \\
information from extension & & & \\
agents & & & \\
I use mobile phone to transact & $52(65.0)$ & $11(13.8)$ & $9(11.3)$ & $8(10.0)$ \\
business with customers & & & \\
I use mobile phone to source for $41(51.3)$ & $19(23.8)$ & & $13(16.3)$ \\
agro-inputs such as chemicals & & & \\
I use mobile phone to source for $43(53.8)$ & $23(28.8)$ & $4(5.0)$ & $10(12.5)$ \\
information on credit facilities & & & \\
\hline
\end{tabular}

Percentage in parentheses

The result in table 5 shows that $93.8 \%$ of the respondents were of the opinion that their income has increased due to new method learnt from agricultural programmes on radio broadcast. Also $90.0 \%$ of the respondents have been enlightened on the various agronomic maize practices through agricultural programmes on radio.71.3\% of the maize farmers in the study areas reported that their customers have increased as a result of advertising their farm on radio. This implies that through agricultural programmes on radio, the maize farmers in the study area have experienced improvement on their production capacity. Majority (97.5\%) of the respondents profit has increased due to increase in their income. 
Assessment of Information and Communication Technologies usage by maize farmers in Afijio local government area of Oyo state

Table 5: Effects of Radio on maize farming $(n=80)$

$\begin{array}{llc}\text { Radio } & \text { Yes } & \text { No } \\ \text { My income has increased due to new methods learnt } & 75(93.8) & 5(6.3) \\ \text { from agric programme } & & \\ \text { Through agric programmes, I have been enlightened on } & 72(90.0) & 8(10.0) \\ \text { various agronomy maize practise } & \\ \begin{array}{l}\text { My customers has increased as a result of advertising my } \\ \text { farm on radio }\end{array} & 23(28.8) \\ \text { My profit has increased due to increase in my income } & 78(97.5) & 2(2.5)\end{array}$

Percentage in parentheses

The result in table 6 shows that $88.8 \%$ of the

other maize farmers. Furthermore, $82.5 \%$ of respondents have received information from the maize farmers found it easier to source extension agents through the use of mobile for agro-inputs with the use of mobile phone phone which serves as a means of better while $86.3 \%$ of the respondents in the study communication. About $90.0 \%$ of the area got information on agencies involved in respondents in the study area reported that agricultural credit facilities through the use the use of mobile phone has greatly of mobile phone. improved their ways of communicating with Table 6: Effects of mobile phone on maize farming $(n=80)$

\begin{tabular}{lll}
\hline Mobile phone & Yes & No \\
\hline $\begin{array}{l}\text { Acquiring information from extension agents is now easier } \\
\text { due to better means of communication }\end{array}$ & $71(88.8)$ & $9(11.3)$ \\
$\begin{array}{l}\text { Communication with other maize farmers and customers has } \\
\text { improved greatly }\end{array}$ & $72(90.0)$ & $8(10.0)$ \\
$\begin{array}{l}\text { Sourcing for agro-inputs is now easier and better done } \\
\text { Information on agencies involved in agric facilities is easier }\end{array}$ & $69(86.3)$ & $14(17.5)$ \\
to get through the use of mobile phone & & $11(13.8)$ \\
\hline
\end{tabular}

Percentage in parentheses 
Assessment of Information and Communication Technologies usage by maize farmers in Afijio local government area of Oyo state

The result in table 7 reveals that insufficient financial resources (63.8\%), high cost of ICT devices (50.0\%), inadequate knowledge on technical know-how (46.3\%) and irregular power supply $(41.3 \%)$ were the major constraints, while cost of maintenance (45.0\%) and high cost of ICT devices $(40.0 \%)$ were the minor constraints experienced by the farmers. ITU (2010) stated that rural people mostly live sparsely and this would make provision of infrastructure and public utilities such as electric power, water, health facilities and some devices of modern ICTs very difficult to deploy in rural areas. Private companies invest their resources in areas where they would get good returns .In addition, provision of ICT services would require electricity and technical know-how which are limited in most places of rural areas. Income of the rural people tends to be low as compared to urban areas and many rural households simply cannot afford modern ICTs such as computer and internet.

Table 7: Constraints to effective use of ICT $(n=80)$

\begin{tabular}{llll}
\hline Constraints & $\begin{array}{l}\text { Major } \\
\text { constraints }\end{array}$ & $\begin{array}{l}\text { Minor } \\
\text { constraints }\end{array}$ & $\begin{array}{l}\text { Not-a } \\
\text { constraints }\end{array}$ \\
\hline Irregular power supply & $33(41.3)$ & $23(28.8)$ & $24(30.0)$ \\
High cost of ICT devices & $40(50.0)$ & $32(40.0)$ & $8(10.0)$ \\
Poor network connection & $19(23.8)$ & $9(11.3)$ & $52(65.0)$ \\
Poor knowledge on technical know-how & $37(46.3)$ & $23(28.8)$ & $20(25.0)$
\end{tabular}

Percentage in parentheses

Table 8 shows that there is significant relationship $(\mathrm{P}<0.01)$ between age, marital status, educational level, secondary occupation, level of employment and utilization of ICT in the study area. This implies that age, marital status, educational level, secondary occupation and level of employment of the respondents had influence on the utilization of ICT in the study area. Nevertheless, the result also shows that there is no significant relationship ( $>0.05)$ between gender and utilization of ICT. This implies that whether you are male or female maize farmer, you can use ICT devices to get information needed on the production of maize. 
Assessment of Information and Communication Technologies usage by maize farmers in Afijio local government area of Oyo state

Table 8: Chi-square analysis on socio-economic characteristics of respondents

\begin{tabular}{lccl}
\hline Variable & $\mathbf{X}^{2}$-value & p-value & Decision \\
\hline Gender & 3.260 & 0.196 & Not significant \\
Age & 34.239 & 0.000 & Significant \\
Marital status & 25.767 & 0.000 & Significant \\
Educational level & 56.892 & 0.000 & Significant \\
Secondary occupation & 20.306 & 0.002 & Significant \\
Level of employment & 7.228 & 0.027 & Significant \\
\hline
\end{tabular}

Correlation coefficient, $r$ significant @ $\mathrm{p}<0.01$

The table above shows that there is the more the maize farmers make use of ICT significant relationship between the extent devices, the more the effects of utilization of of utilization of ICT by maize farmers and the effects of utilization of ICT production. devices $(\mathrm{r}=0.817, \mathrm{p}<0.05)$. This implies that

Table 9: Pearson product moment correlation (PPMC)

\begin{tabular}{llll}
\hline Variables & r-value & p-value & Decision \\
\hline Extent of utilization of ICT by maize & 0.817 & 0.000 & Significant \\
Farmers and the effects of utilization & & & \\
of ICT devices & & & \\
\hline
\end{tabular}

Correlation coefficient, $r$ significant, $p$ @ 5\% level of significance

The table above shows that there is no of ICT devices $(r=0.075, p>0.05)$. This significant relationship between the implies that challenges do not influence constraints of ICT usage and the utilization utilization of ICTs 
Assessment of Information and Communication Technologies usage by maize farmers in Afijio local government area of Oyo state

Table 10: Pearson product moment correlation (PPMC)

\begin{tabular}{llll}
\hline Variables & r-value & p-value & Decision \\
\hline The constraints of ICT usage and & -0.075 & 0.509 & Not significant \\
Utilization of ICT devices & & & \\
\hline
\end{tabular}

Correlation coefficient, $r$ not significant, $\mathrm{p} @ 5 \%$ level of significance

\section{Conclusion}

The study accessed the usage of ICT by maize farmers in Afijio Local Government Area of Oyo State. The socio-economic characteristics of the respondents reveals that male gender were more involved in maize farming with majority of the farmers having one acre which implied limited agricultural practices. The results further showed that radio and mobile phones were the most widely used ICT devices. Majority of the respondents used mobile phones to source for information relevant to their agricultural production. The farmers also received enlightenment programmes on agronomic practices in maize production. Findings therefore showed that mobile phones, radio, television were predominantly used among the respondents in the study area which have given them access to information on innovation and improvements in their production activities.
However, the major constraints encountered by maize farmers in ICT usage were irregular power supply, high cost of ICT devices, and poor technical know-how of ICT devices.

\section{Recommendation}

Maize farmers should be encouraged to access and utilize ICTs by supporting them financially and materially by the governments and private sectors/donor agencies. More awareness and training of both farmers and extension agents on the effective and efficient use of ICT facilities should be intensified by the governments through extension agency. As a developing country, ICT should be integrated to agriculture in order to provide accurate, timely, relevant information and services to maize farmers thereby facilitating good environment for increased agricultural production. Furthermore, the research organisations should ensure that farmers 
Assessment of Information and Communication Technologies usage by maize farmers in Afijio local government area of Oyo state

submit their detailed profile data and phone numbers to receive adequate information on latest agricultural discoveries, expos, and advertisements. Ministry of Agriculture should sign a memorandum of understanding with electricity Distribution Company for constant supply of power to rural areas to ensure their access to information. Extension agents should also encourage farmers to acquire transistor radio with battery cells to enjoy frequent access to information. Government should improve on electricity supply to the rural areas which will enable the farmers to utilize the ICT devices. Finally, the ministry of Agriculture and most research institutes should synergize with social media and telecommunication service providers outfits on latest innovation; and make it available to farmers through the most widely used ICT devices among the farmers generally.

\section{References}

Adejo, P.E. and Haruna,U. (2009). Access of farmers to ICTs for agricultural development in Bauchi Local Government Area, Bauchi State. In proceeding of the $43^{\text {rd }}$ Annual Conference of the Agricultural
Society of Nigeria held in Abuja, 2009. pp 704-707

Akinbile, T. (2007). Technical center for agricultural and rural cooperation ACP-EU(2009). annual report. 2007. DH.Neun. The Netherland. CPA.

Arokoyo, T. (2005). ICTs application in agricultural extension delivery. In: Addoyin, S.F (2005), Agricultural Extension Nigeria. Published by Agricultural Extension Society in Nigeria (AESON), pp245-250.

Anamam, O. (2013). Report on information and communication for development $\left(\mathrm{IC}_{4} \mathrm{I}\right)$ e extending reach and increasing impact. Available online at $h t t p / / w w w . d e v . o r g / e n / a r t i c l e$.

Davis, K.E. and Addom B.K. (2010). Subsaharan Africa in R.Saravanan. Ed. ICTs for Agricultural Extension; Global experiments innovations and experiences. New Delhi.

Food and Agricultural Organisation, FAO (2013). Information and communication technologies for 
Assessment of Information and Communication Technologies usage by maize farmers in Afijio local government area of Oyo state

sustainable agriculture: Indicators

from Asia and the Pacific. Edited

by Gerald Sylvester. Rap

Publication 2013/14.122 pages.

Available at www.fao.org

Gilwald, A. (2010). ICT regulation in Africa. The good, the bad and ugly.

Communication

Technologies Hankbook.BMI-

Techknowledge.

ITU (2010). World Telecommunication/ICT

Development Report 2010.

Monitoring the WSIS targets. A mid-term review. International Telecommunication Union (ITU).

Geneva, Switzerland.

Muriithi, A.G. and Ogaleh, S.A. (2009). Information technology for agriculture and rural development in Africa;Experiences from Kenya. A paper presented at conference on ICT literacy of farmers in Subregion, October 6-8. Available at https://books.google.com.ng>

Nwagwu, Z.O. and Opeyemi, M. (2015). Roles of ICT in agricultural produce. A paper presented at $6^{\text {th }}$ consultative expert meeting of
CTA's observatory on

ICTs;WICC/CTA, 2003,20

Olaniyi, O.A. and Ismaila, K.O. (2016). Information and communication technologies (ICTs) usage and household food security status of maize crop farmers in Ondo State, Nigeria: Implication for sustainable development. Library Philosophy and Practice (e-journal). 1446. Available at http://digitalcommons.unl.edu/libphilp $\underline{\mathrm{rac} / 1446}$

About the authors

Oke Olalekan Oluwole, the lead author, is an Agricultural Extension expert per excellence. He bagged his first degree in Agricultural Extension and Rural Development in 1998 from the Federal University of Agriculture, Abeokuta, Nigeria. Since graduation he has worked with a private organisation till 2011 before joining the Federal College of Forestry, Ibadan, Nigeria in2011 till date as a lecturer/ Researcher. He bagged his M.Sc. in Agricultural Extension and Rural Development in 2017, and $\mathrm{PhD}$ in view from the Federal University of Agriculture, Abeokuta, Nigeria. email: woleok@yahoo.com. ; ; phone: 08034019783.

Adeoye, Adebayo Samson, is the corresponding author of the article. He is a motivated field extension researcher, an 
Assessment of Information and Communication Technologies usage by maize farmers in Afijio local government area of Oyo state

agricultural extensionist per excellence. He bagged his first degree in Agricultural Economics and Extension in 2005 from the Federal University of Agriculture, Makurdi, Benue State, Nigeria. Since graduation he has worked as sales representative with a telecommunication outfit, teacher in secondary school, and as an agricultural superintendent in government service of Ekiti state before joining the services of the Federal College of Forestry, Ibadan, Nigeria in 2011. He has worked as a lecturer and researcher in the department of Agricultural Extension and Management since 2011 till date. He is Master of Science holder in Agricultural Extension and Rural Development (2014) from the prestigious University of Ibadan, Nigeria. $\mathrm{PhD}$ in view in Social Forestry/ Extension and Environmental Development from the University of Ibadan, Nigeria. email: saadeoye06@gmail.com; phone: $08037657876,07036335225$.

Jatto, Kabir Adedayo. $\mathrm{He}$ is an Agricultural Economist. He bagged his first degree in Agricultural Economics and Extension in 2007 from the University of Maiduguri, Maiduguri, Nigeria. Since graduation he has worked with a private organisation till 2011 before joining the Federal College of Forestry, Ibadan, Nigeria till date as a lecturer/ Researcher. $\mathrm{He}$ is currently undergoing his M.Sc. in Agricultural Economics, in view from the University of Ilorin, Ilorin, Nigeria. email: Jattodayo@yahoo.com; phone: 07034598245

Adelusi, Felicia Temitope, one of the authors is a master degree holder in Animal science from Federal University of Agriculture, Abeokuta in 2017. I work as a lecturer/researcher in the Department of Agricultural extension and management of federal college of forestry, ibadan, Oyo state, Nigeria since 2011 till date. email:temmytdoks@gmail.com; phone:+2347038153579

Ojo-fakuade, Folashade Foluso, one of the authors is an excellent teacher of Agricultural Economics. She bagged her first degree in Economics from the Lead City University, Ibadan in 2008. She joined the Federal College of Forestry, Ibadan, Nigeria in March 2012 and till date she has been prolific in the discharge of her duties as a Lecturer / Researcher. She is a Master of Science holder in Agricultural Economics which she obtained from the prestigious University of Ibadan in 2015. email: oluwasegunfakuade@yahoo.com; phone: 08035296741 . 